\title{
Polymeric materials as pour point depressant for Egyptian waxy crude oil
}

\author{
Ahmed Bahgat ${ }^{1 \star}$, H. Salah ${ }^{2}$, M. S. Mansour ${ }^{3}$, D. A. El-Gayar ${ }^{3}$ and M. Abdel-Fattah ${ }^{4}$ \\ ${ }^{1}$ Petrojet Company, Alexandria, Egypt. \\ ${ }^{2}$ El-Amriya Petroleum Company, Alexandria, Egypt. \\ ${ }^{3}$ Chemical Engineering Department, Alexandria University, Alexandria, Egypt. \\ ${ }^{4}$ Petrochemical Engineering Department, Pharos University, PUA, Alexandria, Egypt.
}

Accepted 22 May, 2019

\begin{abstract}
The relation between the temperature of waxy crude oils pipelining and pour point is a well-established phenomenon. Different techniques have been applied to reduce the problems due to crystallization of saturated hydrocarbons during production and transportation of waxy crude oils. Use of pour point depressant (PPD) is preferred economically and effect cost saving. In this work, Poly-methyl acrylic acid hydrazide, modified N-Salicylidene polymer and tin chloride complex was synthesis and characterized by SEM, FTIR, BET and TGA. PPD was evaluated as flow improver in different types of Egyptian waxy crude oils, Alamin (light crude oil) and Qarun (heavy crude oil). The results showed good performance in improving the pour point temperature depending on the composition and the location of waxy crude oil. The optimum amount of PPD for three types of depressants is 500 ppm for both types of Egyptian waxy crude oils.
\end{abstract}

Keywords: Pour point depressant, flow improver, waxy crude oil.

*Corresponding author. E-mail: ahmed.bahgat5553@gmail.com.

\section{INTRODUCTION}

Crude oils consist of linear and branch wax containing a large amount of wax and high viscosities. It often requires specific conditions pressure (i.e. yield stress) to initiate the flow for pipelining. Wax deposition is a serious problem in crude oil production and processing. Waxy crude oils contain significant amount of paraffin waxes and asphaltenes and these components are the main problems in reservoir, production tubing and transportation through pipe (Mahto and Kumar, 2013). Resins are not considered as a deposit on their own, but it deposit with asphaltenes together (Sharma et al., 2012; Venkatesan et al., 2005). Crude oils will stop flowing in a pipeline and following a sudden shutdown of pumping operation, and increase pressure drop across the pipe if the ambient temperature is below its pour point (Hemant and Dinakar, 2006). Several treatments are available to solve this problem like mechanical solutions play an important role such as passing pigs removal, steam tracing and thermal insulation of pipelines can be used
(Galloway, 1992; Sarmento et al., 2014). In addition internal coating of pipes with antistick material, application to modify the crystals and the use of chemical additives, such as organic inhibitors and pour point depressants (PPD), which drops the deposition of waxes and the pour point of the crude oil as well (Lucas et al., 2015; Bucaram, 1967). Pretreatment with flow improver (FI) additives is a solution for transportation of waxy crudes in pipelines. Flow improver additives, also known as pour point depressants (PPD), can reduce the growth of wax crystals and form smaller crystals of higher volume to surface ratio. Due to this change in crystalline shape, the ability of the wax crystals to grow and interlock is reduced. The combination of these effects lowers the pour point, viscosity, and yield stress considerably, making transportation much easier (Holder and Winkler, 1965a; Holder and Winkler, 1965b). In nature, flow improvers are very selective. The affectivity of additives varied according to the type of crude (Sifferman, 1979). 
Some depressants reduction of viscosity and strength do not effect on pour point and besides, the rheological parameters such as viscosity, pour point, and yield stress of the treated crude may regain the original gel structure of the untreated crude, in case of a sudden shut down for a period. However, when an exact fit can be developed, polymeric additives can be remarkably effective in depressing the pour point of waxy crude (Irani and Zajac, 1982). So, we can say that wax content is responsible for flow problems: the crude which has a high quantity of wax contains higher the wax contain, the greater are the flow problems. However, there is no relation between pour point and wax content. Other constituents in the crude oil (i.e., asphaltene, resin, lighter distillates, etc.) also effects on flow behavior. For example, crude oils with high asphaltene contents are also highly viscous (Wardhaugh and Boger, 1987). Moreover, asphaltenes the main factor of waxes formation. They focus on the surface of the wax crystal. In the present work, synthesis of three new pour point depressant to play an important role to drop down pour point for two Egyptian crude oils were selected on the basis of wax and asphaltene contents to minimize wax deposition due to temperature reduction during crude transportation.

\section{EXPERIMENTAL}

\section{Materials}

Methyl acrylate monomer (Merck, assay $\geq 99.5 \%$ ), Potassium bromate, Sodium hydrogen sulfite, Di-methyl sulfoxide (Merck, assay 99\%), Hydrazine hydrates (ALPHA CHEM, 99\%), methanol (SOMATCO, assay $\geq$ 99.7\%), Salsicylaldehyde (Merck, assay 98\%), dimethyl tin dichloride (assay 97\%), chloroform all chemicals used were analytical grade. Two different types of Egyptian waxy crude oils were used for evaluating the performance of synthesis polymer additive.

\section{Physical characteristics of crude oils}

Two paraffinic crude oils are studied in this work, that is, Alamin and Qarun crude oils. Table 1 represents physical characterizations of these crudes.

Table 1. Physical properties of Egyptian waxy crude oils.

\begin{tabular}{lccl}
\hline Properties & Alamin crude oil & Qarun crude oil & ASTM methods \\
\hline API & 39.6 & 37.6 & ASTM D287 \\
Specific gravity, $60 / 60^{\circ} \mathrm{F}$ & 0.825 & 0.8361 & ASTM D-1298 \\
Pour point, ${ }^{\circ} \mathrm{C}$ & 6 & 27 & ASTM D-97 \\
Wax content, wt $\%$ & 3.2 & 5.6 & ASTM D5442 \\
Asphaltene content, wt $\%$ & 0.61 & 1.3 & ASTM D6560 \\
Water, vol \% & 0.01 & 0.01 & ASTM D4006 \\
\hline
\end{tabular}

\section{METHODS}

\section{Synthesis of poly methyl acrylate (based polymer)}

Polymerization of methyl acrylate monomer is carried out using potassium bromate, sodium hydrogen sulfite as initiators. These contents are mixed together in flask till particles starts to grow and quickly turn to milky appearance. Then, the milky emulsion is added to sodium chloride to coagulate the polymer then washed by water to remove unreacted monomer the removed by tweezer.

\section{Synthesis of poly-methyl acrylic acid hydrazide (polymerization reaction)}

Polymerization of methyl acrylate monomer is carried out using Potassium bromate, Sodium hydrogen sulfite to obtain poly methyl acrylate and then reacted with hydrazine hydrate in presence of di-methyl sulphoxide to form poly acrylic acid hydrazide under continuous reflux and stirring then filtered and dried as shown in Figures 1 and 2.

\section{Synthesis of modified N-Salicylidene polymer (polymerization reaction)}

Poly acrylic acid hydrazide which corresponding react with Salicylaldehyde in presence of methanol and distilled water under continuous reflux and stirring then filtered and dried to obtain the new polymer prepared (modified $\mathrm{N}$-Salicylidene polymer) as shown in Figure 3.

Preparation of tin complex from the reaction of $\mathrm{N}$ Salicylidene derivatives of poly acrylic acid hydrazide with dimethyl tin dichloride

A solution of dimethyl tin dichloride in methanol was added drop wise with constant stirring to a suspension of 


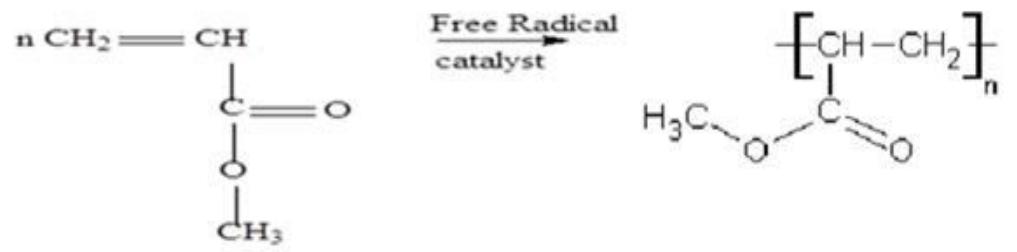

Methyl acrylate monomer

Poly methyl acrylate

Figure 1. Structure of poly-methyl acrylate.

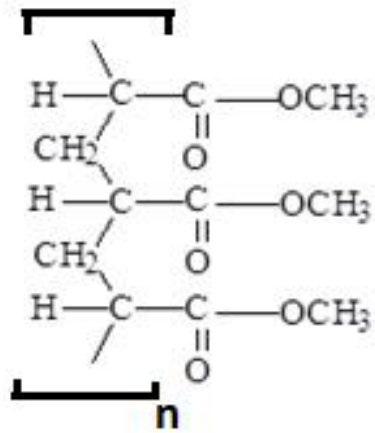

Poly methyl acrylate

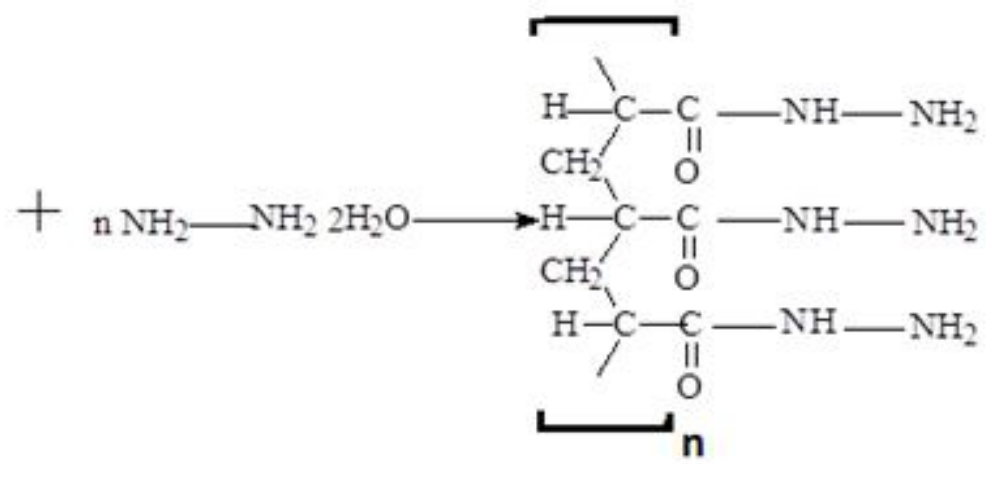

Poly methyl acrylic acid hydrazid

Figure 2. Structure of poly methyl acrylic acid hydrazide.

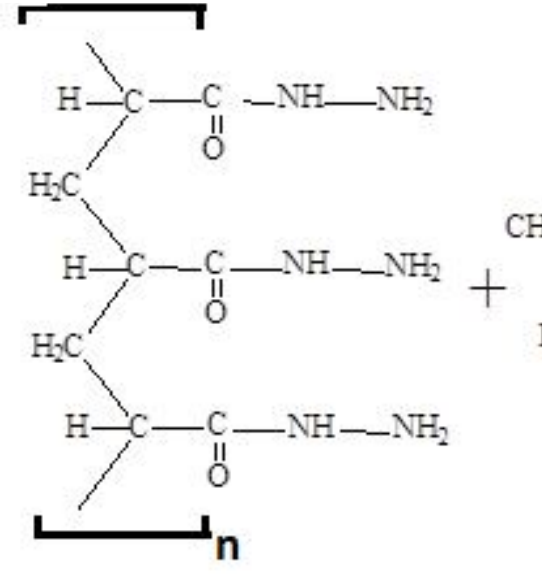

Poly-methyl acrylic acid hydrazide

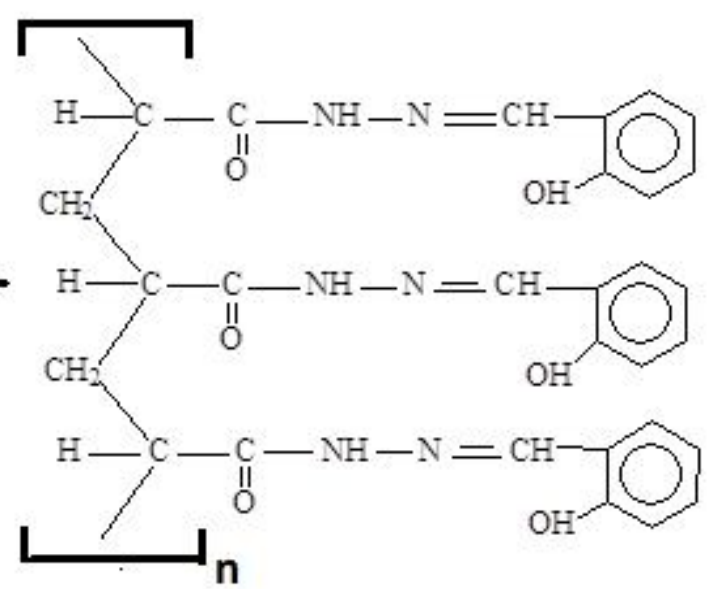

$\mathrm{N}$-Salicylidene poly methyl acrylic acid hydrazide

Figure 3. Structure of modified N-salicylidene polymer.

Modified N-Salicylidene Polymer in methanol, then a solution of sodium metal in methanol was added to it drop by drop. The reaction mixture was boiled under reflux with constant stirring for two hours. On cooling the resulted yellow tin complex was filtrated and washed with methanol. The new product complex is soluble in chloroform.

\section{Pour point measurements (ASTM D-97)}

This test method is intended for use on any petroleum product, a procedure for testing the fluidity of a residual fuel oil at a specified temperature to determine the pour point of crude oil. Pour point in petroleum products is the lowest temperature at which movement of the test 

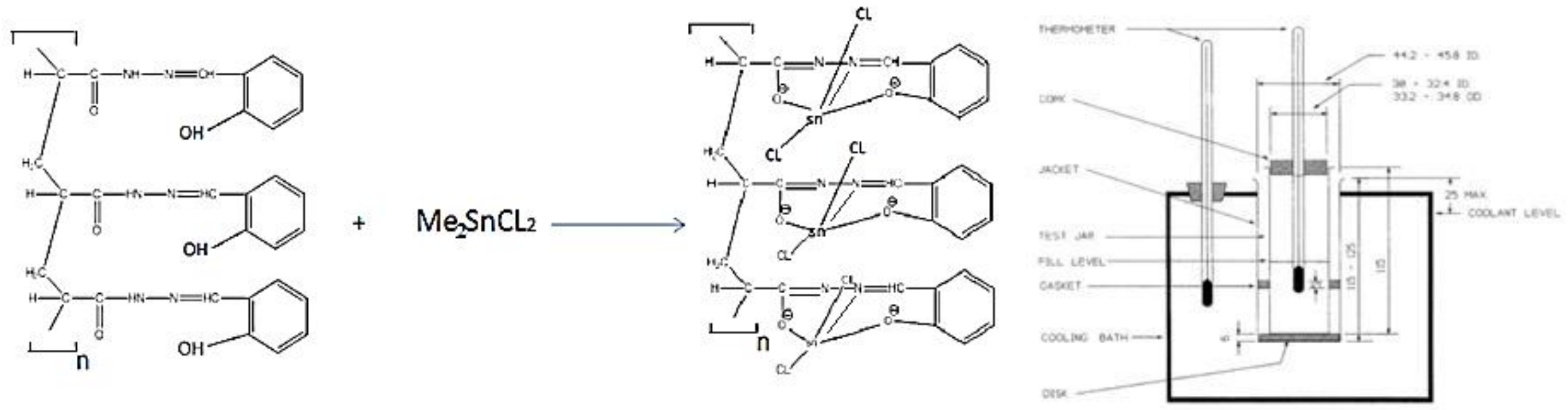

Structure (a)

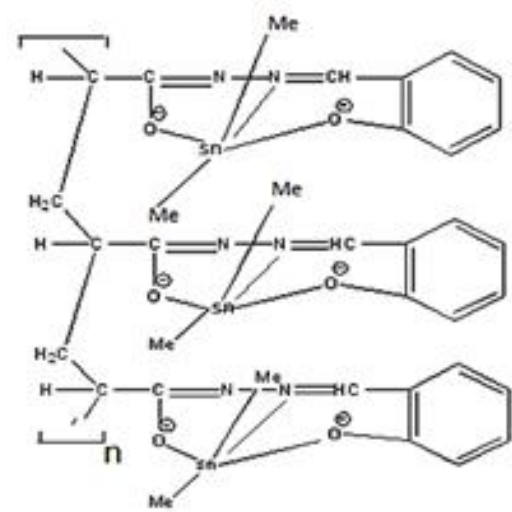

Structure (b)

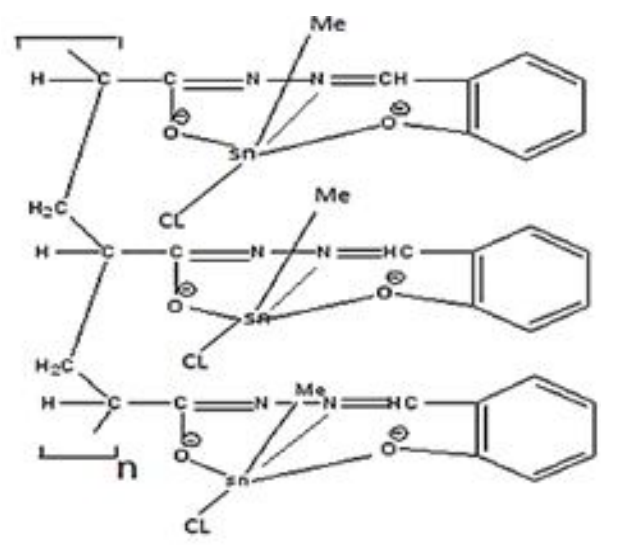

Structure (c)

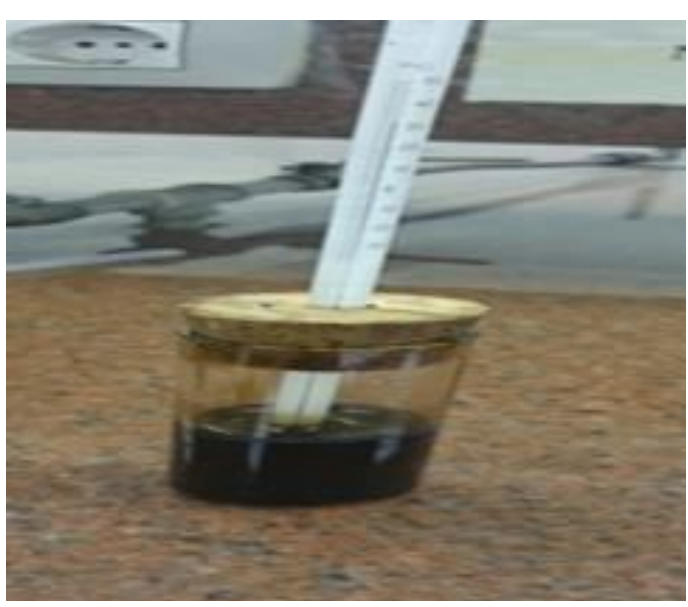

Figure 4. Pour point apparatus

specimen is observed under prescribed conditions of test. After preliminary heating, the sample cooled at specified rate at examined at interval $3^{\circ} \mathrm{C}$ for flow. Characteristics the lowest temperature at which the movement of specimen is observed is recorded as the pour point as it shown in Figure 4.
Characterization methods of prepared polymethyl acrylic acid hydrazide, modified $\mathrm{N}$ Salicylidene polymer and tin chloride complex

\section{Scanning electron microscopy (SEM)}

A scanning electron microscopy (SEM) is a type of electron microscope that produces Images of a sample by scanning it with a focused beam of electrons. The electrons interact with atom in the sample producing varies signals that can be detected and that contain information about the sample's surface topography and composition.

SEM can achieve resolution better than 
1 nanometer. Specimens can be observed in high vacuum, in low vacuum, and (in environmental SEM) in wet conditions. In the present work, the samples prepared were analyzed by using SEM "JEOL JSM 6360L.

\section{FTIR spectroscopy analysis}

The surface functional groups and structure were studied by FTIR spectroscopy. The FTIR spectra of the prepared samples were recorded between 500 and $4000 \mathrm{~cm}^{-1}$ in FTIR- 8400 S Shimadzu. FTIR spectrometer simultaneously collects high spectral resolution data over a wide spectral range. This confers a significant advantage over a dispersive spectrometer which measures intensity over a narrow range of wavelengths at a time.

\section{Brunauer-Emmett-Teller (BET-surface area)}

BET device is used in surface area measurements of powder or batch samples and pore size and pore size distribution. In the present work, the samples prepared were analyzed by using the Belsorp mini ii-Japan. The device determined needed gas quantity to cover the sample surface with a molecular layer and calculate the surface area using Brunauer, Emmett and Teller (BET) theory. Equipment analysis active surface area in $\mathrm{m}^{2} / \mathrm{g}$ unit was carried out with chemical absorption technique. Device can be used in determination of porous structure in raw materials, in applications like moisture or gas detectors. Measureable minimum surface area is 0.05 $\mathrm{m}^{2} / \mathrm{g}$ when nitrogen is used and $0.0005 \mathrm{~m}^{2} / \mathrm{g}$ when cripton is used. Measureable minimum pore size is 3.5$5000 \mathrm{~A}$ with nitrogen and pore volume limits is less than $0.0001 \mathrm{cc} / \mathrm{g}$. BET device, with $1^{\circ} \mathrm{C} / \mathrm{min}$ heating rate, maximum $400^{\circ} \mathrm{C}$ can be achieved. Non-corrosive gases $\left(\mathrm{N}_{2}, \mathrm{Ar}, \mathrm{CO}_{2}, \mathrm{C}_{4} \mathrm{H}_{10}\right.$ etc.), corrosive steam) $\mathrm{NH}_{3}$ cyclohexane etc) can be used. For the analysis, a quantity of powder or massive sample that corresponds to $12-15 \mathrm{~m}^{2}$ is used.

\section{Thermo gravimetric analysis (TGA)}

The thermo grams in air were obtained on a mettle TA3000 System at a heating rate of $10 \mathrm{~K} / \mathrm{min}$ at room temperature under atmospheric pressure taking $0.2 \mathrm{~g}$ of copolymer sample in a platinum crucible

\section{RESULTS AND DISSCUSSION}

\section{Morphology study (SEM) of prepared materials of PPD}

SEM images with different levels of magnifications factor for the prepared poly acrylic acid hydrazide, modified $\mathrm{N}$ salicylidene polymer and tin chloride complex as a pour point depressant with magnifications factor 35000,15000 and 10000 respectively is shown in Figures $5 a$ and b, 6a and $b$ and $7 a$ and $b$. These results show that polymers prepared is small spherical shape and smooth surface like agglomerate.

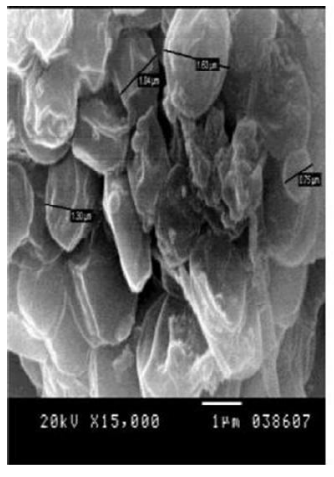

(a)

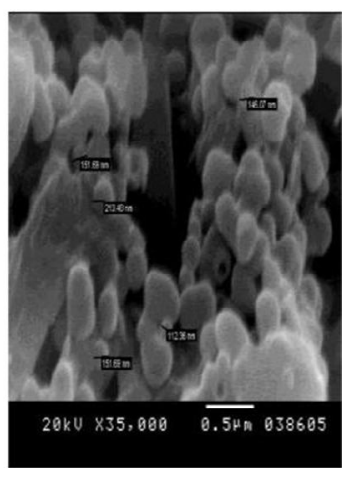

(b)
Figure 5. a) SEM of poly-methyl acrylic acid hydrazide with magnification factor 15000 . b) SEM of poly-methyl acrylic acid hydrazide with magnification factor 35000 .

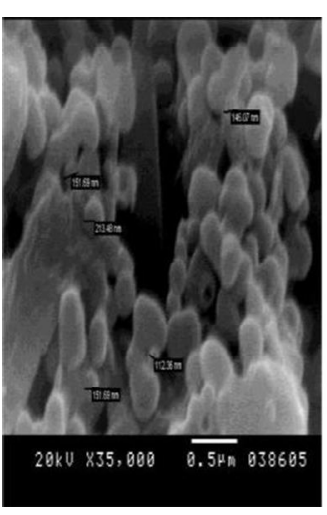

(a)

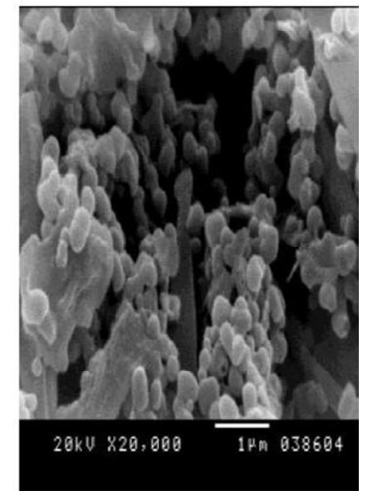

(b)
Figure 6. a) SEM of modified N-salicylidene polymer with magnification factor 35000 . b) SEM of modified N-Salicylidene polymer with magnification factor 20000 .

\section{Surface area}

BET device is used in surface area measurements of powder or batch samples and pore size and pore size distribution as shown in Table 2.

The highest surface area for modified N-Salicylidene polymer due to the addition of high molecular weight of 


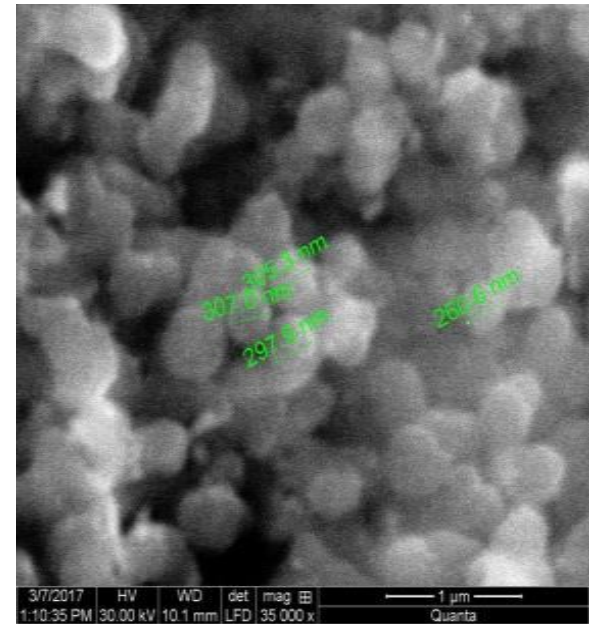

(a)

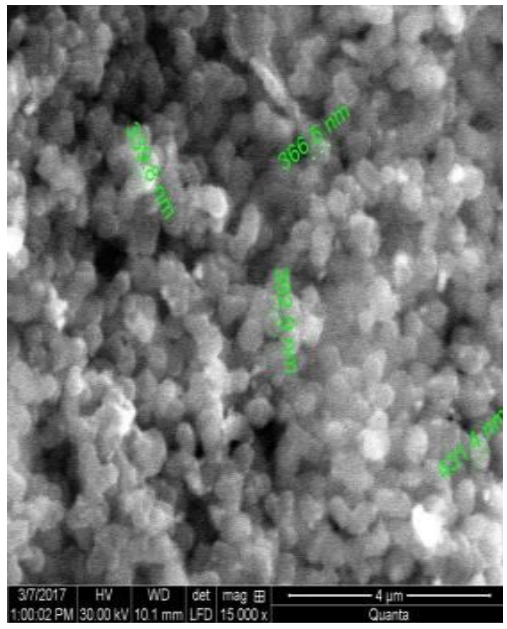

(b)

Figure 7. a) SEM of tin chloride complex with magnification factor 35000. b) SEM of tin chloride complex with magnification factor 15000 .

Table 2. BET surface area for hydrazine, modified $\mathrm{N}$-salicylidene polymer and tin chloride complex.

\begin{tabular}{|c|c|c|c|}
\hline \multicolumn{2}{|c|}{ Flename CoNvert } & \multirow{2}{*}{$\begin{array}{l}\text { Adsorptive } \\
\text { Adssorpoon tempeczane } \\
\mathrm{s} 2 \\
\text { naw }\end{array}$} & \multirow{2}{*}{ 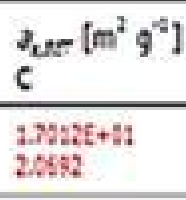 } \\
\hline $\begin{array}{l}\text { poty acrylic acid } \\
\text { hydrazide }\end{array}$ & 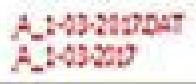 & & \\
\hline $\begin{array}{l}\text { modified N-Salicylidene } \\
\text { polymer }\end{array}$ & B.:-103:20vost & ${ }_{n 2}^{n}$ & $\begin{array}{l}7.78: 45+: 1 \\
3.3553\end{array}$ \\
\hline Tin chloride complex & 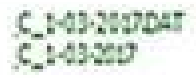 & $\begin{array}{l}\mathrm{N} \\
\mathrm{n}\end{array}$ & $\begin{array}{l}2.45 a c \cdot 64 \\
12.513\end{array}$ \\
\hline
\end{tabular}

salicylaldehyde, and poly acrylic acid hydrazide also give good indication for improving the pour point.

\section{Fourier transform infra-red (FTIR) analysis of prepared materials of PPD}

IR spectra of the prepared polymers are analyzed on IR spectra using FTIR-8400 Shimadzu instrument as shown in Figures 8, 9 and 10.

Figure 8 show that the spectra of hydrazine polymer as a series of bands characteristic to the hydrazide (-CO$\mathrm{NH}-\mathrm{NH}_{2}$ ) residue. In the $3450-3100 \mathrm{~cm}^{-1}$ region spectra exhibited a number of bands due to $\mathrm{U}_{\text {sym }}\left(\mathrm{NH}_{2}\right)$ symmetric stretching vibration and $U_{\text {asym }} \quad\left(\mathrm{NH}_{2}\right)$ asymmetric stretching vibration of the $\left(3200 \mathrm{~cm}^{-1}\right)$ attributable to $\mathrm{U}(\mathrm{NH})$ of the secondary $\mathrm{NH}$ group. Similar to amides, the hydrazide group also showed the spectra of hydrazine polymer also showed IR bands due to both $\mathrm{C}=\mathrm{O}$ In plane deformation and out of plane deformation respectively at
$656 \mathrm{~cm}^{-1}$.

Figure $9 \mathrm{IR}$ spectra of $\mathrm{N}$-Salicylidene polymer showed the amide 1 bond $\mathrm{C}=\mathrm{O}$ at $1623 \mathrm{~cm}^{-1}$ while amide 2, 3 and 4 appeared respectively at 1573,1203 and $679 \mathrm{~cm}^{-1}$. In addition to these bonds, the spectra showed strong bond at $1661 \mathrm{~cm}^{-1}$ due to $\mathrm{C}=\mathrm{N}$. In most cases the phenolic group $[\mathrm{OH}]$ of the $\mathrm{N}$-Salicylidene derivatives cannot be identified due to the strong inter hydrogen bonding with $\mathrm{C}=\mathrm{N}$.

The IR spectra of tin chloride complex polymer did not lack any absorption due to $\mathrm{NH}_{2}$. The IR Spectrum of tin complex polymer shows $\mathrm{NH}$ bond at $3000 \mathrm{~cm}^{-1}$ beside a strong bond at $1615 \mathrm{~cm}^{-1}$ attributable to coordination $\mathrm{C}=\mathrm{O}$ amide 1 bond. The amide 2 and 3 and amide 4 appear at 1573,1201 and $656 \mathrm{~cm}^{-1}$, respectively.

Comparison of IR spectra of tin complex with the uncoordinated $\mathrm{N}$-Salicylidene polymer reveal that the amide 1 bond is shifted towards lower frequencies $8 \mathrm{~cm}^{-1}$ due to coordination of the hydrazide carbonyl oxygen due to the central of ion metal. 


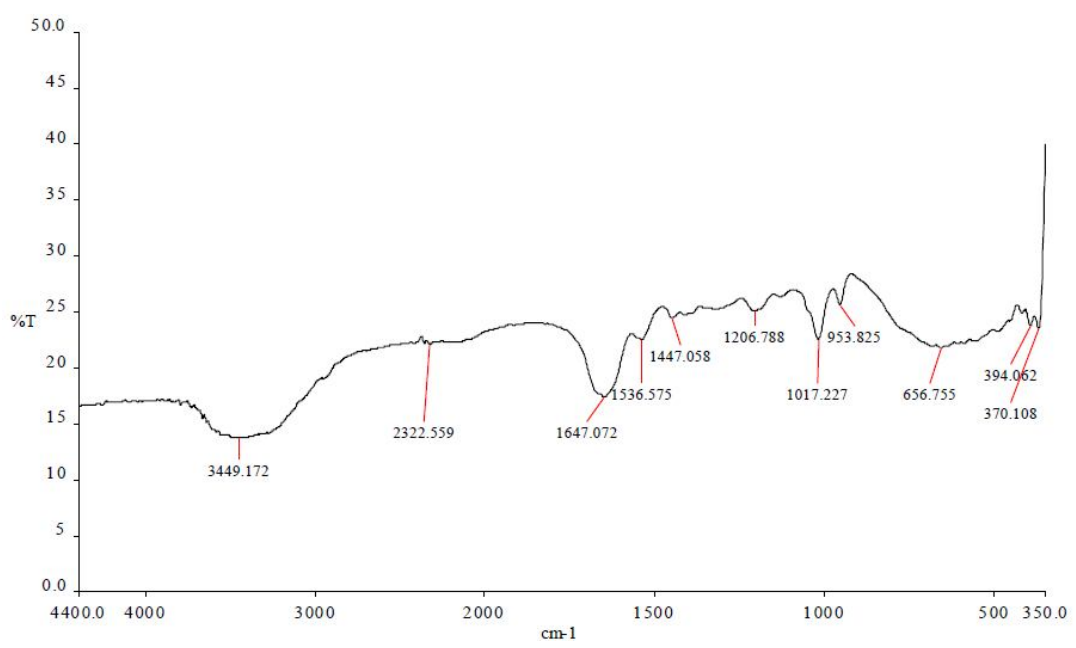

Figure 8. FTIR of poly-methyl acrylic acid hydrazide.

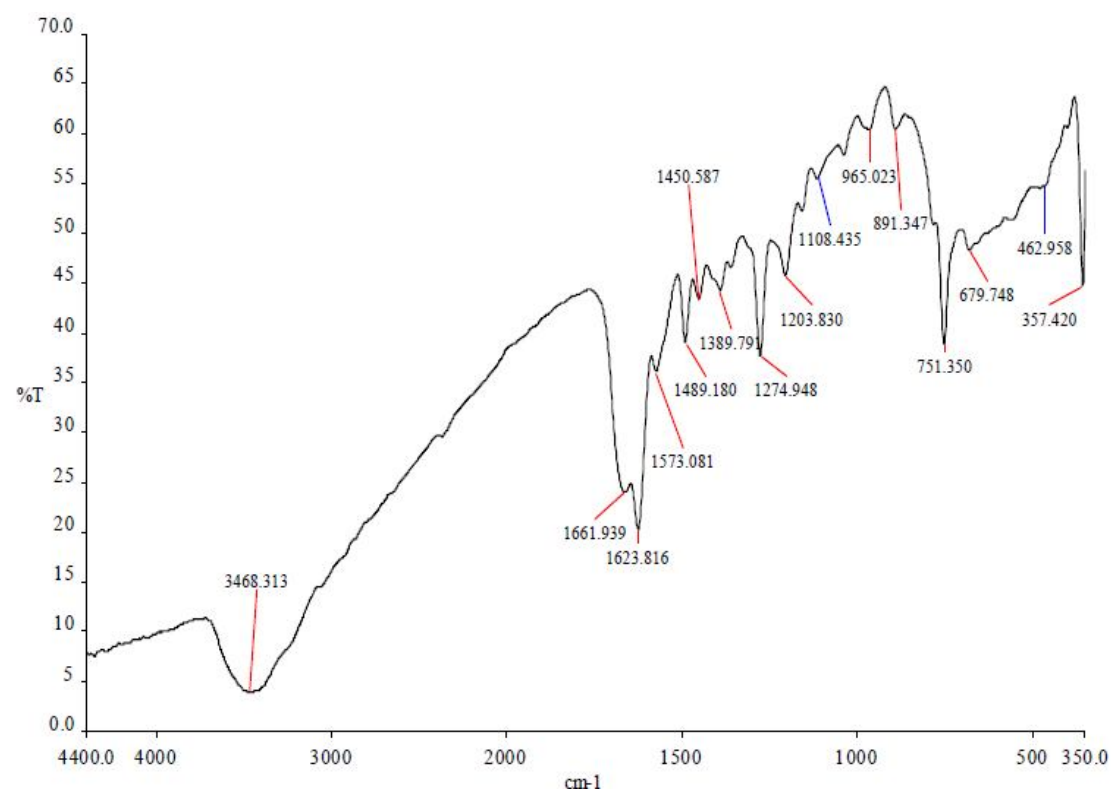

Figure 9. FTIR of modified N-salicylidene polymer.

\section{Thermo gravimetric analysis of prepared materials as PPD}

TGA curves of poly acrylic acide hydrazide in Figure 11 shows many stages where stage 1 occurs in temperature range $\left(61\right.$ to $\left.117.7^{\circ} \mathrm{C}\right)$ due to small loss of $\mathrm{H}_{2} \mathrm{O}$ (entrained water) $3.36 \%$ loss. Stage 2 and stage 3 occur in temperature range $\left(117.7\right.$ to $\left.239.9^{\circ} \mathrm{C}\right)$ due to continuous rapture and releasing $\mathrm{NH}-\mathrm{NH}_{2}$ in the whole molecules which represent about $37.2 \%$. Stage 4 occurs in temperature range $\left(239.9\right.$ to $\left.323.8^{\circ} \mathrm{C}\right)$ due to rapture of $\mathrm{C}=\mathrm{O}$ bond in the whole molecule. Stage 5 occurs in temperature range $\left(323.8\right.$ to $\left.445.9^{\circ} \mathrm{C}\right)$ due to rapture between [C-C] bond in the molecule. The last two stages occur in the temperature range $\left(445.9\right.$ to $\left.598.8^{\circ} \mathrm{C}\right)$

Modified N-Salicylidene polymer as shown in Figure 12, stage 1 occurs at temperature range $\left(32.7\right.$ to $\left.162.8^{\circ} \mathrm{C}\right)$ due to small loss of $\mathrm{H}_{2} \mathrm{O}$ molecules (entrained water) $7.1 \%$ loss, while stage 2 and stage 3 occur in temperature range $\left(162.8\right.$ to $\left.369.79^{\circ} \mathrm{C}\right)$ due to the continuous double bond rapture between $\mathrm{N}=\mathrm{CH}$ in the whole molecule which represent about $54 \%$ loss, the last stage occur in temperature range $\left(369.7\right.$ to $\left.598.2^{\circ} \mathrm{C}\right)$ due to further molecule degradation.

Figure 13 shows the TGA of tin chloride complex, when stage 1 occurred at temperature range $\left(58.5\right.$ to $\left.191.1^{\circ} \mathrm{C}\right)$ due to loss of $\mathrm{H}_{2} \mathrm{O}$ molecule (entrained water $3.5 \%$ ).

Stage 2 occurs in the temperature range (191.7 to 


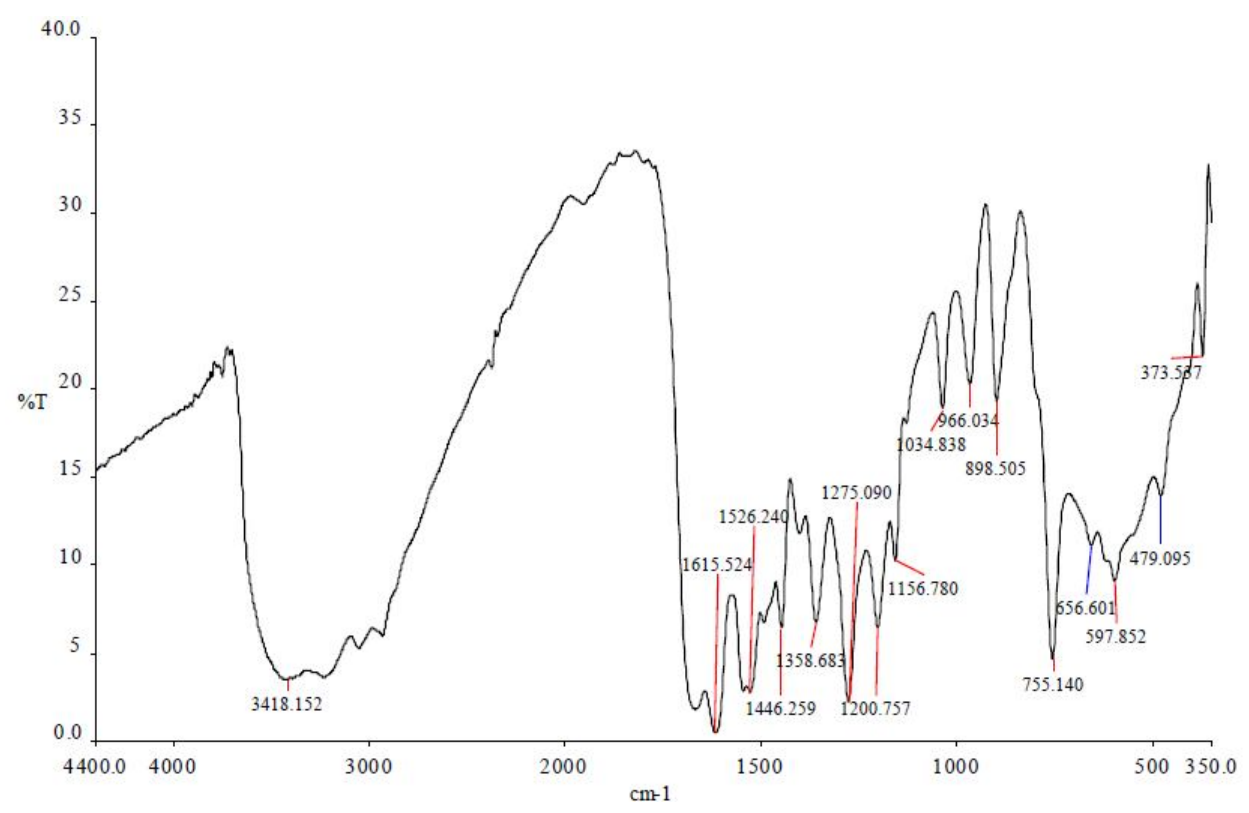

Figure 10. FTIR of tin chloride complex.

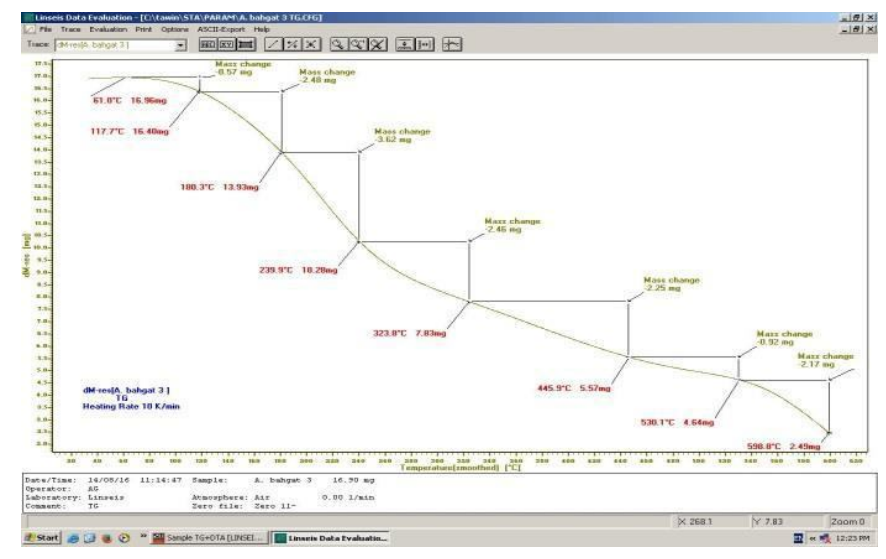

Figure 11. TGA of poly-methyl acrylic acide hydrazide.

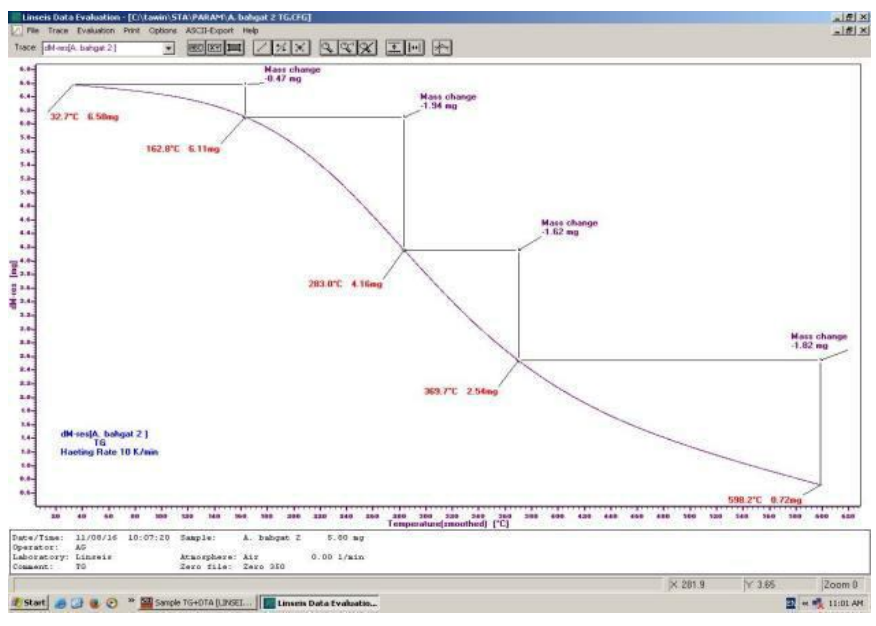

Figure 12. TGA of modified N-salicylidene polymer. $420.4^{\circ} \mathrm{C}$ ) due to dissociation of metal complex formed.

Comparison of effect between different types of poly acrylic acid hydrazide, modified $\mathrm{N}$-Salicylidene and tin chloride complex on Alamin crude oil

Figure 14 shows a comparison among different types of pour point depressants poly acrylic acid hydrazide, modified N-Salicylidene and tin chloride complex concentration (ppm) on Alamin crude oil. It is obviously shows that the pour point stay constant at $6^{\circ} \mathrm{C}$ as poly acrylic acid hydrazide concentration increase till 300 ppm, while modified $\mathrm{N}$-salicylidene and tin chloride complex both drop the pour point to $3^{\circ} \mathrm{C}$ at $300 \mathrm{ppm}$. In addition, the three depressant have the same performance at $400 \mathrm{ppm}$ and pour point become $3^{\circ} \mathrm{C}$ and then dramatically dropped from 3 to $0^{\circ} \mathrm{C}$ at $500 \mathrm{ppm}$. The results obtained that poly acrylic acid hydrazide, modified $\mathrm{N}$-saliclidene and tin chloride complex make the best performance at $500 \mathrm{ppm}$.

\section{Comparison of effect between different types of poly acrylic acid hydrazide, modified $\mathrm{N}$-Salicylidene and tin chloride complex on Qarun crude oil}

Figure 15 shows a comparison among different types of pour point depressants poly acrylic acid hydrazide, modified N-Salicylidene and tin chloride complex concentration (ppm) on Qarun crude oil. It obviously shows that the pour point stay constant at $27^{\circ} \mathrm{C}$ as poly acrylic acid hydrazide, modified $\mathrm{N}$-salicylidene and tin chloride complex concentration increase at 100 ppm, 


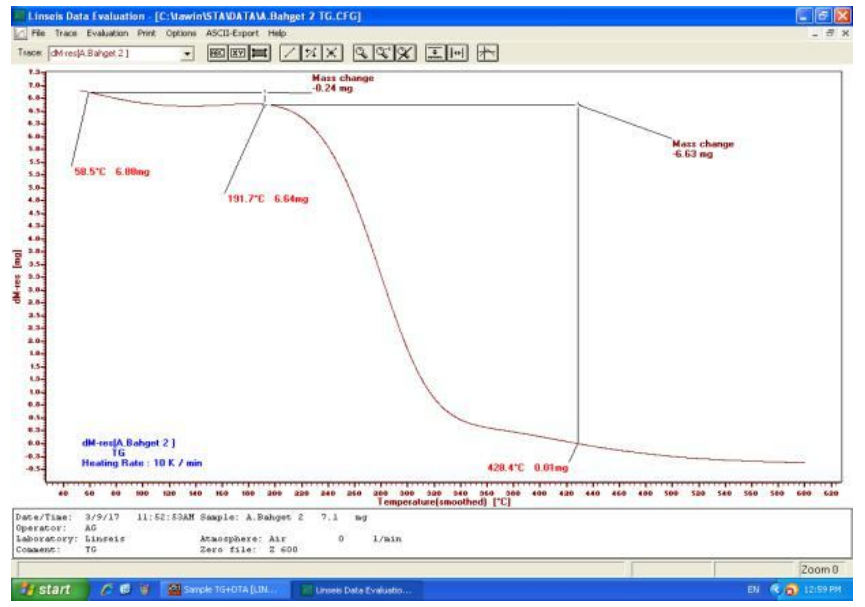

Figure 13. TGA of tin chloride complex crystal.

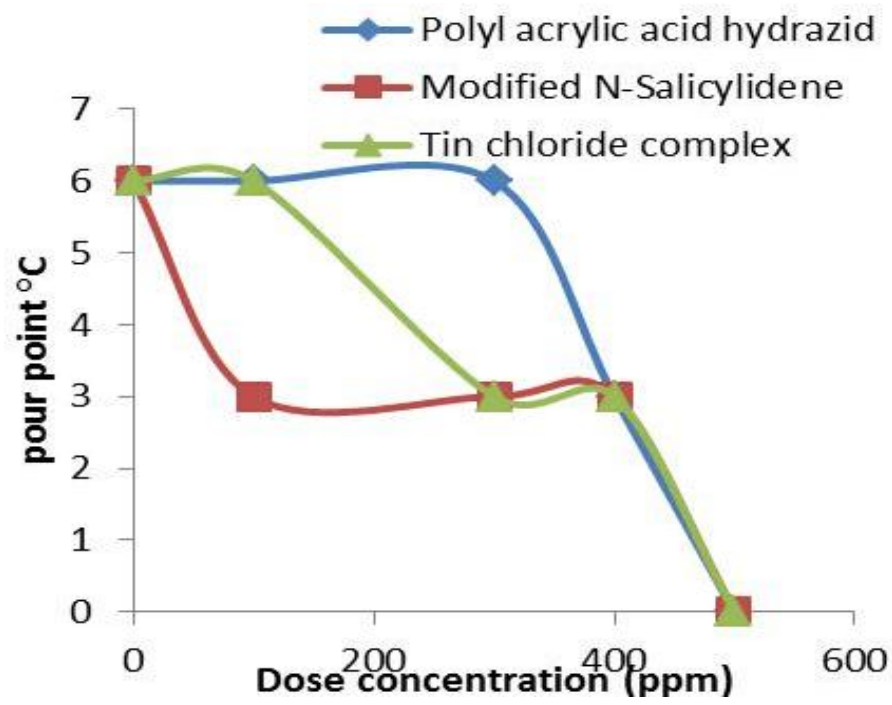

Figure 14. Comparison between three pour point depressant on Alamin crude oil.

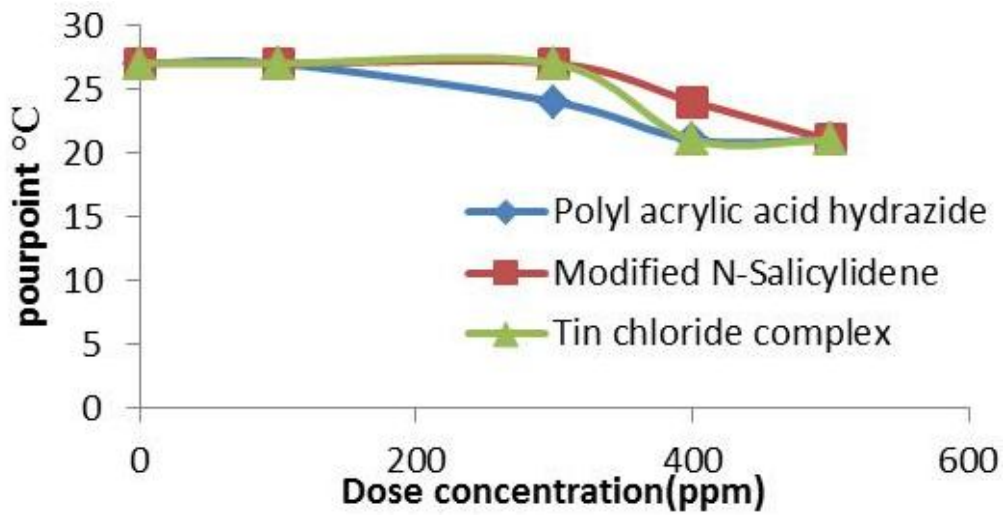

Figure 15. Comparison between three pour point depressant on Qarun crude oil. 


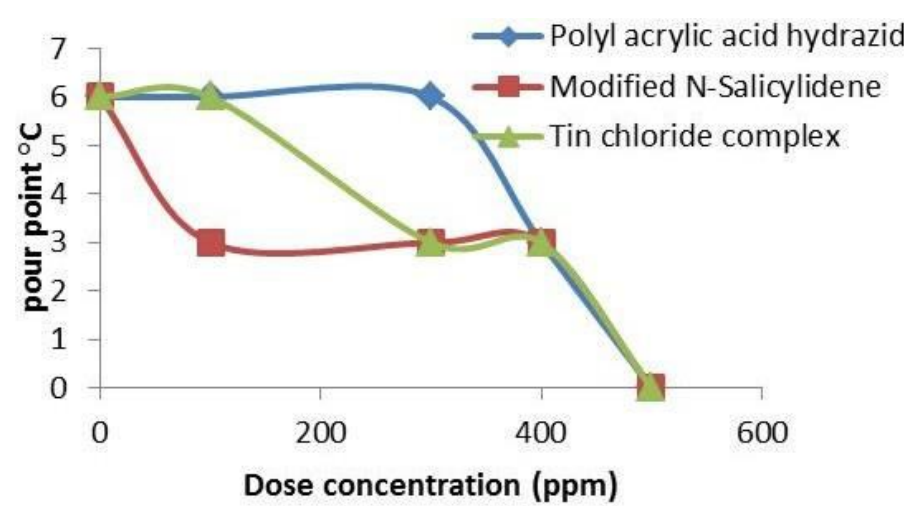

Figure 16. Comparison between three pour point depressant on Alamin crude oil after two hours.

while in case of poly acrylic acid hydrazide the pour point decreased to $24^{\circ} \mathrm{C}$ at $300 \mathrm{ppm}$. In addition, the increasing concentration of poly acrylic acid hydrazide and tin chloride complex to $400 \mathrm{ppm}$ reduce the pour point to $21^{\circ} \mathrm{C}$. The pour point becomes constant at $500 \mathrm{ppm}$ and reach to $21^{\circ} \mathrm{C}$ for the three depressants. It obtained from the results that modified $\mathrm{N}$-Salicylidene and tin chloride complex is recommended for Qarun crude oil at $400 \mathrm{ppm}$.

Comparison of effect between different types of poly acrylic acid hydrazide, modified $\mathrm{N}$-salicylidene and tin chloride complex on Alamin crude oil after two hours

Figure 16 shows a comparison among different types of pour point depressants poly acrylic acid hydrazide, modified N-Salicylidene and tin chloride complex concentration (ppm) on Alamin crude oil after two hours. It obviously shows that the pour point stays constant at $6^{\circ} \mathrm{C}$ as poly acrylic acid hydrazide concentration increase till $300 \mathrm{ppm}$, while modified $\mathrm{N}$-salicylidene and tin chloride complex both drop the pour point to $3^{\circ} \mathrm{C}$ at 300 ppm. In addition, the three depressant have the same performance at $400 \mathrm{ppm}$ and pour point become $3^{\circ} \mathrm{C}$ and then dramatically dropped from 3 to $0^{\circ} \mathrm{C}$ at $500 \mathrm{ppm}$.the results obtained that poly acrylic acid hydrazide, modified $\mathrm{N}$-salicylidene and tin chloride complex make the best performance at $500 \mathrm{ppm}$. This result is in agreement with the literature of Borthakur et al. (1996).

Comparison of effect between different types of poly acrylic acid hydrazide, modified $\mathrm{N}$-salicylidene and tin chloride complex on Qarun crude oil after two hours

Figure 17 shows a comparison among different types of pour point depressants poly acrylic acid hydrazide, modified $\mathrm{N}$-salicylidene and tin chloride complex (ppm) on Qarun crude oil after two hours. It obviously shows that the pour point stay constant at $27^{\circ} \mathrm{C}$ as poly acrylic acid hydrazide, modified $\mathrm{N}$-salicylidene and tin chloride complex concentration increase at 100 ppm, while in case of poly acrylic acid hydrazide the pour point decreased to $24^{\circ} \mathrm{C}$ at $300 \mathrm{ppm}$. In addition, the increasing concentration of poly acrylic acid hydrazide and tin chloride complex to $400 \mathrm{ppm}$ reduce the pour point to $21^{\circ} \mathrm{C}$. The pour point becomes constant at $500 \mathrm{ppm}$ and reaches $21^{\circ} \mathrm{C}$ for the three depressants. It is obtained from the results that modified $\mathrm{N}$-salicylidene and tin chloride complex are recommended for Qarun crude oil at $400 \mathrm{ppm}$. The result obtained after two hours is that there is no effect of time on the performance of poly acrylic acid hydrazide, modified $\mathrm{N}$-salicylidene and tin chloride complex.

Comparison of effect between different types of poly acrylic acid hydrazide, modified $\mathrm{N}$-salicylidene polymer and tin chloride complex on Alamin crude oil after 24 hours

Figure 18 shows a comparison among different types of pour point depressants poly acrylic acid hydrazide, modified N-salicylidene and tin chloride complex concentration (ppm) on Alamin crude oil after $24 \mathrm{~h}$. It is obviously shows that the pour point stay constant at $6^{\circ} \mathrm{C}$ as poly acrylic acid hydrazide and tin chloride complex concentration increase at $100 \mathrm{ppm}$, while modified $\mathrm{N}$ salicylidene drops the pour point to $3^{\circ} \mathrm{C}$ at $100 \mathrm{ppm}$. In addition, the three depressants have the same performance at $300 \mathrm{ppm}$ and pour point become $3^{\circ} \mathrm{C}$ and then pour point dramatically dropped from 3 to $0^{\circ} \mathrm{C}$ at 400 ppm for poly acrylic acid hydrazide and modified $\mathrm{N}$ salicylidene, while pour point in case of tin chloride complex stayes constant at $3^{\circ} \mathrm{C}$ when the concentration increase to $400 \mathrm{ppm}$. The results obtained that poly acrylic acid hydrazide and modified $\mathrm{N}$-salicylidene gives the best performance at $400 \mathrm{ppm}$ of Alamin crude oil.

\section{Comparison of effect between different types of poly- acrylic acid hydrazide, $\mathrm{N}$-salicylidene and tin chloride complex on Qarun crude oil after 24 hours}

Figure 19 shows a comparison among different types of pour point depressants poly-acrylic acid hydrazide, modified N-salicylidene and tin chloride complex concentration (ppm) on Qarun crude oil after $24 \mathrm{~h}$. It obviously shows that the pour point stay constant at $27^{\circ} \mathrm{C}$ as poly acrylic acid hydrazide, modified $\mathrm{N}$-salicylidene and tin chloride complex concentration increase at 100 ppm, while in case of poly-acrylic acid hydrazide the pour point decreased to $21^{\circ} \mathrm{C}$ at $300 \mathrm{ppm}$. In addition, the increasing concentration of modified $\mathrm{N}$-salicylidene polymer to $300 \mathrm{ppm}$ reduces the pour point to $24^{\circ} \mathrm{C}$. The pour point becomes constant at $400 \mathrm{ppm}$ and reached 


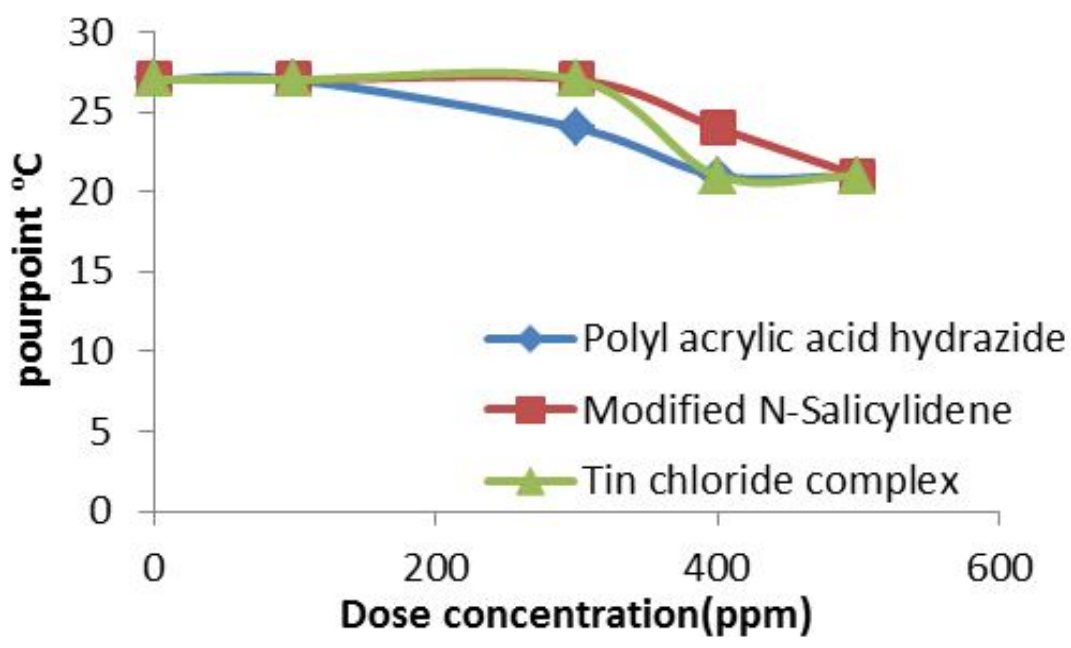

Figure 17. Comparison between three pour point depressants on Qarun crude oil after two hours.

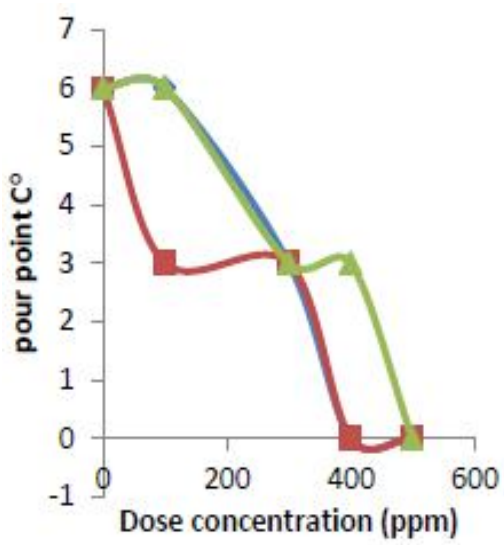

Figure 18. Comparison between three pour point depressant on Alamin crude oil after 24 hours.

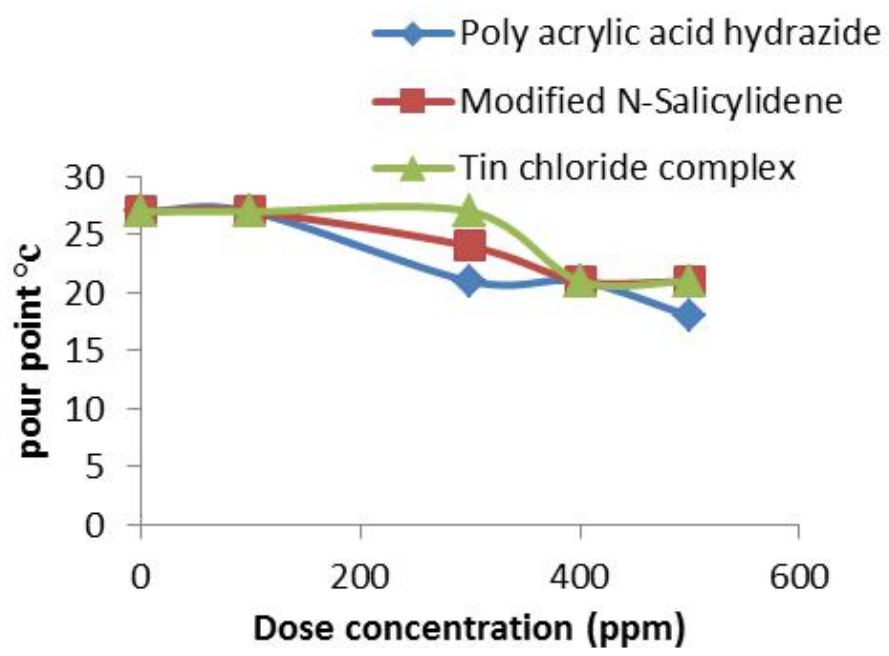

Figure 19. Comparison between three pour point depressant on Qarun crude oil after 24 hours. $21^{\circ} \mathrm{C}$ for the three depressants. on the other hand, the pour point decreased sharply to $18^{\circ} \mathrm{C}$ at $500 \mathrm{ppm}$ in case of using poly acrylic acid hydrazide.it obtained from the results that poly acrylic acid hydrazide has best performance on Qarun oil at 500 ppm .

\section{Comparison between modified $\mathrm{N}$-salicylidene polymer prepared and different other pour point depressant (PPD) additives}

As shown in Table 3 , there are many PPD that can be used for different types of waxy crude oil. The modified $\mathrm{N}$-salicylidene polymer prepared shows similar performance as the PPD in the literature.

\section{CONCLUSIONS}

A new materials had been prepared that are effective for improving the flow of both types of Egyptain waxy crude oil, different polymeric additives were synthesized and characterized in the laboratory and their effects on pour point were investigated. All the additives satisfy most of the requirements to act as a pour point depressant and flow improvers. Based on the results of this study, the conclusion can be drawn in the following:

Modified $\mathrm{N}$-salicylidene polymer has the highest surface area for the three prepared materials that works as pour point depressant on two different type of Egyptian waxy crude oil Alamin and Qarun.

The tin chloride complex has the most stable compound for temperature degradation which indicate low surface area corresponding to the other materials prepared that confirm the presence in a complex form.

The three PPD prepared show good results for Alamin and Qarun crude oil at 500 ppm that decrease the pour 
Table 3. Comparison between prepared flow improvers and other PPD additives.

\begin{tabular}{|c|c|c|c|c|c|c|c|}
\hline \multirow{3}{*}{ Crude type } & \multicolumn{5}{|c|}{ Concentration in ppm } & \multirow{3}{*}{ PPD used } & \multirow{3}{*}{ Reference no. } \\
\hline & \multicolumn{5}{|c|}{ Pour point ${ }^{\circ} \mathrm{C}$} & & \\
\hline & Nil & 100 & 300 & 400 & 500 & & \\
\hline Alamin(Egypt) & 6 & 6 & 6 & 3 & 0 & Poly-methyl acrylic acide hydrazide & Current work \\
\hline Qarun (Egypt) & 27 & 27 & 24 & 21 & 21 & Poly-methyl acrylic acide hydrazide & Current work \\
\hline Alamin(Egypt) & 6 & 6 & 3 & 3 & 0 & Tin chloride crystal & Current work \\
\hline Qarun (Egypt) & 27 & 27 & 27 & 21 & 21 & Tin chloride crystal & Current work \\
\hline Alamin(Egypt) & 6 & 3 & 3 & 3 & 0 & Modified N-Salicylidene polymer & Current work \\
\hline Qarun (Egypt) & 27 & 27 & 24 & 21 & 21 & Modified N-Salicylidene polymer & Current work \\
\hline BH (Indian) & 30 & -- & 12 & 9 & 9 & Alkyl Fumarate-Vinyl Acetate Copolymer & Borthakur et al. (1996) \\
\hline MRN (Indian) & 30 & -- & 15 & 12 & 9 & Alkyl Fumarate-Vinyl Acetate Copolymer & Borthakur et al. (1996) \\
\hline GLK (Indian) & 33 & -- & 15 & 12 & 12 & Alkyl Fumarate-Vinyl Acetate Copolymer & Borthakur et al. (1996) \\
\hline Khalda (Egypt) & 14 & 11 & 14 & 14 & 14 & NAFOL2022methaacrylate homopolymer & El-Gamal et al. (1994) \\
\hline Salam(Egypt) & 21 & 9 & 3 & 3 & 0 & NAFOL2022methaacrylate homopolymer & El-Gamal et al. (1994) \\
\hline Khalda (Egypt) & 14 & 14 & 14 & 14 & 14 & NAFOL1822methaacrylate homopolymer & El-Gamal et al. (1994) \\
\hline Salam(Egypt) & 21 & 6 & 3 & 3 & 0 & NAFOL1822methaacrylate homopolymer & El-Gamal et al. (1994) \\
\hline Khalda (Egypt) & 14 & 5 & 11 & 14 & 14 & $\begin{array}{l}\text { NAFOL2022acrylate- NAFOL2022 metha acrylate } \\
\text { copolymer }\end{array}$ & El-Gamal et al. (1994) \\
\hline Salam(Egypt) & 21 & 18 & 9 & 3 & 3 & $\begin{array}{l}\text { NAFOL2022acrylate- NAFOL2022 metha acrylate } \\
\text { copolymer }\end{array}$ & El-Gamal et al. (1994) \\
\hline Khalda (Egypt) & 14 & -1 & 5 & 5 & 8 & NAFOL2022acrylate-vinyl acetate copolymer & El-Gamal et al. (1994) \\
\hline Salam(Egypt) & 21 & 15 & 0 & 0 & 0 & NAFOL2022acrylate-vinyl acetate copolymer & El-Gamal et al. (1994) \\
\hline
\end{tabular}

point from 6 to $0^{\circ} \mathrm{C}$ and from 27 to $21^{\circ} \mathrm{C}$, respectively. The three PPD prepared are very stable with time in high performance as staying overnight means the additive is stable with time.

\section{REFERENCES}

Borthakur A, Chanda D, Dutta Choudhury SR, Rao KV, Subrahmanyam B (1996). Alkyl fumarate-vinyl acetate copolymer as flow improver for high waxy Indian crude oils. Energy Fuels, 10: 844848.

Bucaram SM (1967). U.S. Pat. (3): 344,859.

El-Gamal M, Ghuiba FM, El-Batanoney MH, Gobiel S (1994). Synthesis and evaluation of acrylate polymers for improving flow properties of waxy crude. J Appl Polym Sci, 52: 9-19.

Galloway DR (1992). U.S. Pat. 5: 168,929.

Hemant SS, Dinakar PB (2006). Synthesis and evaluation of polymeric additives as flow improvers for Indian crude oil. Iran Polym J, 15(12): 943-954

Holder GA, Winkler JJ (1965a). Wax crystallization from distillate fuels (3 parts). Inst Pet, 51: 228-252.

Holder GA, Winkler JJ (1965b). Crystal-growth poisoning of n-paraffin wax by polymeric additives and its relevance to polymer crystallization mechanisms. Nature, 207: 719-721.

Irani C, Zajac J (1982). Handling of high pour point west-African crude oils. J Pet Technol, 34:289-298.

Lucas EF, Ferreira LS, Khalil CN (2015). Polymers applications in petroleum production. Fifth ed, Encyclopedia of Polymer Science and Technology, New York.

Mahto V, Kumar A (2013). Effect of several parameters on wax deposition in the flow line due to Indian waxy crude oil. Int J Appl Eng Res Dev, 4(3): 1-10.

Sarmento RC, Ribbe GAS, Azevedo LFA (2014). Wax blockage removal by inductive heating of subsea pipelines. Heat Transf Eng, $7(25): 2-12$
Sharma S, Mahto V, Sharma V, Parkash V (2012). To Study the Effect of Flow Improvers on Indian Waxy Crude Oil. Presented at the Second International Conference on Drilling Technology held in Chennai, India.6 - 8.ICDT.

Sifferman TR (1979). Flow properties of difficult-to-handle waxy crude oils. J Pet Technol, 31: 1042-1050.

Venkatesan R, Nagarajan NR, Paso K, Yi YB, Sastry AM, Fogler HS (2005). The strength of paraffin gels formed under static and flow conditions. Chem Eng Sci, 60:3587-3598.

Wardhaugh LT, Boger DV, 1987. Measurement of the unique flow properties of waxy crude oils. Chem Eng Res Design, 65: 74-83.

Citation: Bahgat A, Salah H, M ansour M S, El-Gayar DA, Abdel-Fattah M (2019). Polymeric materials as pour point depressant for Egyptian waxy crude oil. Afr J Eng Res, 7(2): 45-56. 